\title{
Role of rhizosphere and soil properties for the phytomanagement of a salt marsh polluted by mining wastes
}

\author{
H. M. Conesa $\cdot$ A. María-Cervantes • \\ J. Álvarez-Rogel · M. N. González-Alcaraz
}

Received: 18 January 2012/Revised: 19 April 2012/ Accepted: 30 April 2013/Published online: 17 May 2013

(C) Islamic Azad University (IAU) 2013

\begin{abstract}
The goal of this study was to evaluate the soil properties and their modifications within the rhizosphere of spontaneous vegetation as key factors to assess the phytomanagement of a salt marsh polluted by mining wastes. A field survey was performed based on a plot sampling design. The results provided by the analyses of rhizospheric soil $(\mathrm{pH}$, electrical conductivity (EC), organic carbon, total nitrogen, etc.) and metal(loid)s' phytoavailability (assessed by EDTA) were discussed and related to plant metal uptake. The averages of $\mathrm{pH}$ and EC values of the bulk soil and rhizospheric samples were in the range of neutral to slightly alkaline ( $\mathrm{pH} 7-8)$ to saline $\left(>2 \mathrm{dS} \mathrm{m}^{-1}\right)$, respectively. Heavy metal and As concentrations (e.g. $\sim 600 \mathrm{mg} \mathrm{kg}^{-1} \mathrm{As}, \sim 50 \mathrm{mg} \mathrm{kg}^{-1} \mathrm{Cd}, \sim 11,000 \mathrm{mg} \mathrm{kg}^{-1}$ $\mathrm{Pb}$ ) were higher in the rhizosphere for both total and EDTA-extractable fraction. Phragmites australis uptaked the highest concentrations in roots (e.g. $\sim 66 \mathrm{mg} \mathrm{kg}^{-1} \mathrm{As}$, $\sim 1,770 \mathrm{mg} \mathrm{kg}^{-1} \mathrm{Zn}$ ) but not in shoots, for which most of plant species showed low values for $\mathrm{Zn}\left(<300 \mathrm{mg} \mathrm{kg}^{-1}\right)$ but not for $\mathrm{Cd}\left(>0.5 \mathrm{mg} \mathrm{kg}^{-1}\right)$ or $\mathrm{Pb}\left(\sim 20-40 \mathrm{mg} \mathrm{kg}^{-1}\right)$. Vegetation distribution in the studied salt marsh looked to be more affected by salinity than by metal pollution. The free availability of water for plants and the incoming nutrient-enriched effluents which flow through the salt marsh may have hindered the metal(loid)s' phytotoxicity. The phytomanagement of these polluted areas employing the spontaneous vegetation is a good option in order to
\end{abstract}

H. M. Conesa ( $₫)$ · A. María-Cervantes · J. Álvarez-Rogel · M. N. González-Alcaraz

Department of Science and Agricultural Technology, Technical

University of Cartagena, Paseo Alfonso XIII, 48, 30203

Cartagena, Spain

e-mail: hector.conesa@upct.es improve the ecological indicators and to prevent the transport of pollutants to nearby areas.

Keywords Arsenic - Heavy metals - Mining pollution · Phytoavailability $\cdot$ Salinity $\cdot$ Salt marshes

\section{Introduction}

The spread of mining wastes into natural ecosystems has caused the contamination of huge areas worldwide (e.g. Dudka and Adriano 1997; Conesa and Schulin 2010). Heavy metals containing mining wastes, such as $\mathrm{Cd}, \mathrm{Cu}$, $\mathrm{Pb}$, or $\mathrm{Zn}$, are known by their adverse effects on the environment and human health. Salt marsh and wetland ecosystems play an important ecological role due to the sustaining of endemic flora and fauna. The occurrence of salt marshes in the vicinity of mining areas may disturb their environmental quality and be a way of transferring pollutants into the food chain. It is known that within determinate thresholds, these ecosystems show some buffer capacity to external stresses and may immobilize and/or transform harmful compounds (Mitsch and Gosselink 2007). However, high levels of pressure for long periods may lead to their irreversible deterioration (Viaroli et al. 2007) and to their transformation into sources of pollution (Weis and Weis 2004).

The use of constructed wetlands to treat heavy metal wastewater coming from mining activities has been already shown by some authors (O'Sullivan et al. 2004; ÁlvarezRogel et al. 2007a). This role of 'green filter' is based on the biogeochemical processes which occur in wetlands, where vegetation plays an important role (Weis and Weis 2004). In salt marshes, plant metal uptake is species dependent and is controlled by abiotic factors such as $\mathrm{pH}$ 
redox potential, metal speciation, and salinity (Dhir et al. 2009). The flooding dynamics in salt marshes cause changes in the aforementioned factors which constantly modify metal balance in the soil-plant system (Williams 2002). In addition, vegetation in salt marshes plays an important role in controlling metal(loid)s' mobility since it is known that rhizosphere may modify soil parameters such as redox conditions, $\mathrm{pH}$, organic matter content, and microbial activity (Wenzel 2009; González-Alcaraz et al. 2011)

Plants can immobilize metals through uptake into roots or aboveground parts (Weis and Weis 2004), forming rhizoconcretions or plaque onto roots (Prasad et al. 2006) or binding metals through the release of root exudates (Weis et al. 2002). On the other hand, some authors have shown that part of the metals uptaked by plants may be released back to the environment via leaf excretions or leaf deposition onto topsoil (Weis et al. 2002; Caçador et al. 2009). In addition, metal leaching may also occur by rhizosphere acidification (Wang and Benoit 1996) and/or preferential flow through root pathways (Robinson et al. 2008). Therefore, it is necessary to determine the benefits and drawbacks of using plants to immobilize these metals (María-Cervantes et al. 2010). This option is called phytomanagement (Robinson et al. 2009; Domínguez et al. 2008) and describes the engineering or manipulation of soil-plant systems to control pollutant fluxes in the environment, reducing the environmental risks posed by elevated concentrations of these elements in the soil. Plants affect evapotranspiration rates; mobilize, immobilize, or extract metals and other chemicals from soil; introduce organic matter into soil; and also release a variety of chemicals by exudation (Robinson et al. 2006). This approach is adequate for the case of mining-polluted salt marshes, where the long-term ecological sustainability of the system is required in order to sustain an endemic flora and fauna.

The goal of this study was to evaluate the soil properties and their modifications within the rhizosphere of spontaneous vegetation as key factors to assess the further phytomanagement of a salt marsh polluted by mining wastes located at south-east Spain. For that purpose a soil and plant survey was performed in spring 2009 following a plot sampling design. The results provided by the analyses of soil parameters and metal bioavailability assessed with EDTA were discussed and related to plant metal uptake.

\section{Materials and methods}

Area description

Sampling site was located at the Marina del Carmoli salt marsh (240 ha, $37^{\circ} 41^{\prime} \mathrm{N} ; 0^{\circ} 50^{\prime} \mathrm{W}$, Fig. 1). The semi-arid climate of the zone is typically Mediterranean with an annual rainfall around $250-300 \mathrm{~mm}$, concentrated mainly during spring and autumn. The annual average temperature is $18{ }^{\circ} \mathrm{C}$. The Marina del Carmoli belongs to the protected landscapes of the Mar Menor Lagoon (one of the biggest hypersaline coastal lagoons in the Mediterranean Sea). Two water courses flow into the salt marsh: the Rambla de Miranda, which receives the leachates from the nearby agricultural area of Campo de Cartagena Plain, and the Rambla del Miedo, which carries sediments from the former nearby mining area of Cartagena-La Unión (ÁlvarezRogel et al. 2006). The latter constituted an important mining area for more than 2,500 years, ceasing activity in 1991. The ore deposits of this zone have iron, lead, and zinc as the main metal components. Environmental consequences of mining waste discharges into the Mar Menor lagoon were already reviewed by Conesa and Jiménez (2007).

\section{Sampling}

A plot sampling survey was performed employing $10 \times 10 \mathrm{~m}^{2}$ plots (in total, 9 plots). The study was focused in the area (of around 16 ha) within the salt marsh which, according to Jiménez-Cárceles et al. (2008), was polluted by heavy metals (Fig. 1). Plots were distributed randomly through the selected area, and the existing plant species were recorded and sampled (Table 1). Plant samples consisted of shoots and roots. For each selected plant species, three or more repetitions were taken. Each single root and green/dry shoot (when available) sample consisted of a composite sample taken by bulking three single subsamples of that species within a plot. Three repetitions of the corresponding rhizospheric soils were taken below the selected plant species. Each single soil sample consisted of a composite sample taken by mixing three rhizospheric soils of that species within a plot. The rhizospheric soil was obtained after shaking plant roots into plastic bags. In addition, a nonrhizospheric soil sample (bulk soil) was taken per plot consisting of a composite sample from four points.

Soils were air-dried, sieved to $<2 \mathrm{~mm}$, homogenized, and stored in plastic bags prior to laboratory analysis.

\section{Analyses}

$\mathrm{pH}$ and electrical conductivity (EC) were determined in a 1:2.5 soil:deionized water suspension (Rayment and Lyons 2011) using a Crison Basic $20 \mathrm{pH}$ meter and Crison Basic 30 conductivimeter, respectively. Particle size distribution was determined following the method of Bouyoucos densimeter (Gee and Bauder 1986). Equivalent calcium carbonate was determined using Bernard calcimeter (Hulseman 1966; Muller and Gastner 1971). Total organic 


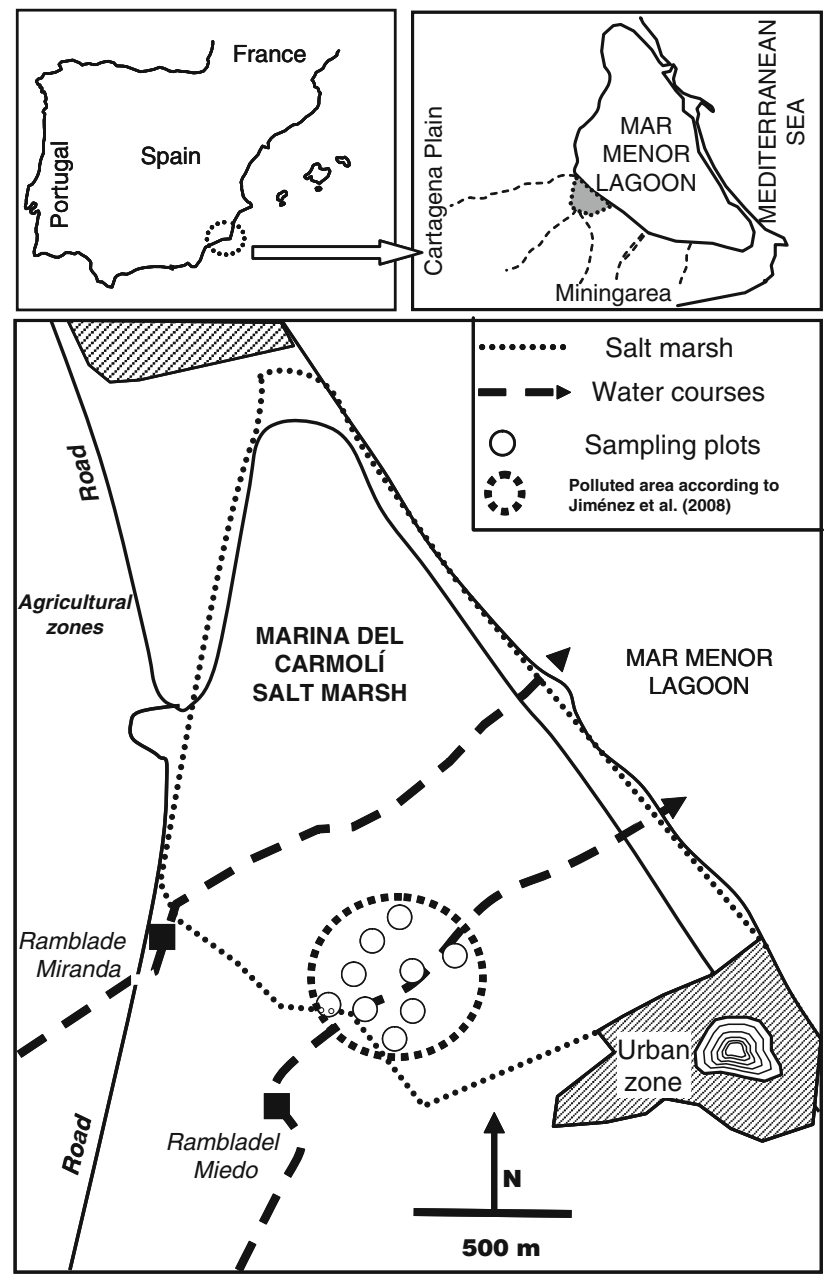

Fig. 1 Location of studied area including location of sampling plots carbon (TOC) was measured by an automatic analyser (TOC-VCSH Shimadzu). Total nitrogen (TN) was determined using the Kjeldahl method (USDA 1996).

The phytoavailable $\mathrm{As}, \mathrm{Cd}, \mathrm{Cu}, \mathrm{Mn}, \mathrm{Pb}$, and $\mathrm{Zn}$ were extracted using a 1:5 soil:EDTA mixture (Quevauviller et al. 1998) that was shaken for $2 \mathrm{~h}$. After filtering (Albet 145 filter, $1-11 \mu \mathrm{m}$ pore diameter), the resulting extracts were analysed using an ICP-MS (Agilent 7500A, detection limit $0.002 \mathrm{mg} \mathrm{L}^{-1}$ ). The use of EDTA as a reagent for the assessment of metal(loid)s' phytoavailability has been widely applied in polluted sites (Nowack and Van Briesen 2005; Aguilar et al. 2007).

Total $\mathrm{As}, \mathrm{Cd}, \mathrm{Cu}, \mathrm{Mn}, \mathrm{Pb}$, and $\mathrm{Zn}$ were determined following the USEPA 3052 method (USEPA 1996). An aliquot of $0.5 \mathrm{~g}$ soil was digested in Teflon tubes with $5 \mathrm{~mL} \mathrm{HNO}_{3}(65 \%)$ and $2 \mathrm{~mL} \mathrm{HF}(40 \%)$ using a microwave digester (ETHOS Touch Control). The digests were filtered through an Albet 145 filter (1-11 $\mu \mathrm{m}$ pore diameter), diluted to $50 \mathrm{~mL}$ with $\mathrm{H}_{3} \mathrm{BO}_{3}(5 \%)$ acid, and analysed using an ICP-MS (Agilent 7500A, detection limit $0.002 \mathrm{mg} \mathrm{L}^{-1}$ ) for As, $\mathrm{Cd}$, and $\mathrm{Cu}$ or an AAS (UNICAM 969, detection limit $0.2 \mathrm{mg} \mathrm{L}^{-1}$ ) for $\mathrm{Mn}, \mathrm{Pb}$, and $\mathrm{Zn}$. Total soil concentration analyses were referenced using a CRM027-050 Certified Material (Resource Technology Corporation, USA). The percentage of recoveries were $112 \%$ for As, $84 \%$ for $\mathrm{Cd}, 117 \%$ for $\mathrm{Cu}, 115 \%$ for $\mathrm{Mn}$, $78 \%$ for $\mathrm{Pb}$, and $100 \%$ for $\mathrm{Zn}$.

Plant samples (separated into green and dry shoots, when possible) were washed with distilled water, dried at $80{ }^{\circ} \mathrm{C}$ for $72 \mathrm{~h}$, and then ground using an IKA A11 basic mill. An aliquot of $0.6 \mathrm{~g}$ was digested using $5 \mathrm{ml}$ of $\mathrm{HNO}_{3}$

Table 1 List of plant species found in the sampling plots studied

\begin{tabular}{|c|c|c|c|}
\hline Latin name & Family & Most common habitat in Mediterranean area ${ }^{\mathrm{a}}$ & Life forms $\mathrm{s}^{\mathrm{a}}$ \\
\hline A. macrostachyum (Moric.) Moris & Chenopodiaceae & Wetlands and salt marshes & Nanophanerophyte \\
\hline Asparagus stipularis Forssk ${ }^{\mathrm{b}}$ & Liliaceae & Thickets & Phanerophyte \\
\hline Atriplex halimus $\mathrm{L}$. & Chenopodiaceae & Soils near the sea & Nanophanerophyte \\
\hline Dittrichia viscosa (L.) Greuter ${ }^{\mathrm{b}}$ & Compositae & Fields, path and road sides, disturbed zones & Nanophanerophyte \\
\hline Foeniculum vulgare L. ${ }^{\mathrm{b}}$ & Umbelliferae & Cultivated fields, path and road sides, disturbed zones & Hemicryptophyte \\
\hline Halimione portulacoides L. (Aellen) & Chenopodiaceae & Salt marshes, salty coastal soils & Chameophyte \\
\hline Juncus maritimus Lam. & Juncaneae & Wetlands and salt marshes & Geophyte \\
\hline Limonium cossonianum Kuntze & Plumbaginaceae & Salt marshes and coastal rocks & Chameophyte \\
\hline Lygeum spartum $\mathrm{L}$. & Gramineae & Salty soils in semi-arid regions & Hemicryptophyte. \\
\hline Phragmites australis (Cav.) Trin ex. Steudel & Gramineae & Wetlands and salt marshes & Geophyte \\
\hline Scirpus holoschoenus L. ${ }^{\mathrm{b}}$ & Cyperaceae & Marshes and intermittent watercourses & Hemicryptophyte \\
\hline Sarcocornia fruticosa (L.) A. J. Scott & Chenopodiaceae & Wetlands and salt marshes & Nanophanerophyte \\
\hline Suaeda vera Forsskal ex J.F. Gmel. & Chenopodiaceae & Salty areas, coastal rocks & Nanophanerophyte \\
\hline Tamarix boveana Bunge & Tamaricaceae & Salty soils & Macrophanerophyte \\
\hline
\end{tabular}

a According to UIB (2007)

b Plant species non-native to this salt environment 
$50 \%(\mathrm{v} / \mathrm{v})+2.5 \mathrm{ml}$ of a reagent solution containing $\mathrm{Mg}\left(\mathrm{NO}_{3}\right)_{2} \cdot 6 \mathrm{H}_{2} \mathrm{O} 20 \%(\mathrm{w} / \mathrm{v})+\mathrm{MgO} 2 \%$ (w/v) (Ybáñez et al. 1991). The $\mathrm{Mg}$ reagent accelerates the oxidation of the organic matter and prevents the volatilization of As (Damkröger et al. 1997). The porcelain crucibles containing the samples were put in a sand bath at a maximum temperature of $130{ }^{\circ} \mathrm{C}$ until drying. The pellet obtained was incinerated in a muffle furnace at $450{ }^{\circ} \mathrm{C}$ for $12 \mathrm{~h}$ prior to a metal redilution using $0.6 \mathrm{~N}$ nitric acid. The resulting extracts were filtered through an Albet 145 ashless filter paper (7-11 $\mu \mathrm{m}$ pore diameter), and then $\mathrm{Cu}, \mathrm{Mn}, \mathrm{Zn}, \mathrm{Cd}$, $\mathrm{Pb}$, and $\mathrm{As}$ contents were measured using an ICP-MS (Agilent 7500A, detection limit $0.002 \mathrm{mg} \mathrm{L}^{-1}$ ). Plant analyses were referenced using a CTA-VTL-2 certified material (Virginia tobacco leaved). The percentage of recoveries were $110 \%$ for $\mathrm{As}, 89 \%$ for $\mathrm{Cd}, 119 \%$ for $\mathrm{Cu}$, $104 \%$ for $\mathrm{Mn}, 96 \%$ for $\mathrm{Pb}$, and $100 \%$ for $\mathrm{Zn}$.

SPSS 15.0.0 (SPSS, Chicago, IL, USA) was used for all statistical analyses $(t$ test). Differences at $P<0.05$ level were considered significant. Environmental gradients were examined with principal component analysis (PCA) using the 'CANOCO for Windows' program v4.02 (ter Braak and Smilauer 1999). This analysis can be applied to environmental variables in the 'role of species' (ter Braak and Smilauer 1999). The analysis was centred and standardized by species (i.e. environmental variables) according to Jogman et al. (1987) and ter Braak and Smilauer (1999). Data were logarithmically transformed prior to analysis.

\section{Results and discussion}

\section{Soil properties}

The averages of $\mathrm{pH}$ values of the bulk and rhizospheric samples (Table 2) were in the range of neutral to slightly alkaline ( $\mathrm{pH}$ 7-8) soils according to the classification proposed by USDA (2005). Only three rhizospheric soils showed values lower than 7: A. stipularis, $\mathrm{pH}$ 6.53; $P$. australis, $\mathrm{pH}$ 5.72; and $S$. holoescens, $\mathrm{pH}$ 6.81. All the soil samples, both rhizospheric and bulk ones, showed (EC) values higher than $2 \mathrm{dS} \mathrm{m}^{-1}$, and therefore, they can be considered as extremely saline (EC $>2 \mathrm{dS} \mathrm{m}^{-1}$ ) according to the classification proposed by Alarcón-Vera (2004) to describe the agricultural soils in South Spain. The EC values showed higher variability than $\mathrm{pH}$ ones, which resulted in several significant differences in relation to bulk soils: A. stipularis $\left(8.93 \mathrm{dS} \mathrm{m}^{-1}\right), F$. vulgare $\left(2.70 \mathrm{dS} \mathrm{m}^{-1}\right)$, and L. cossonianum $\left(12.64 \mathrm{dS} \mathrm{m}^{-1}\right)$.

The total nitrogen (TN) and organic carbon (OC) values were higher in rhizospheric soils than in bulk samples, but these differences resulted only significant for $\mathrm{TN}$ in three cases: $F$. vulgare, $L$. cossonianum, and $S$. fruticosa.
In relation to the particle size distribution, there were no significant differences between rhizospheric and bulk soils. The texture ranged from loam to clay loam.

Total and EDTA metal and As concentrations

The soils in the Marina del Carmoli salt marsh were found to be especially polluted with $\mathrm{As}, \mathrm{Cd}, \mathrm{Pb}$, and $\mathrm{Zn}$ (Table 3) when comparing the concentrations obtained with those that previous authors found after the Aznalcollar toxic spill (1998, South Spain), which was considered recently one of the most important environmental catastrophes in Europe. The polluted soils from Doñana averaged $122 \mathrm{mg} \mathrm{kg}^{-1}$ As, $2.3 \mathrm{mg} \mathrm{kg}^{-1} \mathrm{Cd}, 153 \mathrm{mg} \mathrm{kg}^{-1} \mathrm{Cu}, 360 \mathrm{mg} \mathrm{kg}^{-1} \mathrm{~Pb}$, and $647 \mathrm{mg} \mathrm{kg}^{-1} \mathrm{Zn}$ (Simón et al. 1999). In contrast, soil samples from the Marina del Carmoli showed around 300-600 $\mathrm{mg} \mathrm{kg}^{-1} \mathrm{As}, 30-50 \mathrm{mg} \mathrm{kg}^{-1} \mathrm{Cd}, \sim 200-300 \mathrm{mg} \mathrm{kg}^{-1} \mathrm{Cu}$, 8,000-11,000 $\mathrm{mg} \mathrm{kg}^{-1} \mathrm{~Pb}$, and 12,000-20,000 $\mathrm{mg} \mathrm{kg}^{-1} \mathrm{Zn}$. Soils from the nearby Cartagena plain (Fig. 1) were found to have a geochemical background of $12.6 \mathrm{mg} \mathrm{kg}^{-1} \mathrm{Cu}$, $9 \mathrm{mg} \mathrm{kg}^{-1} \mathrm{~Pb}$, and $41 \mathrm{mg} \mathrm{kg}^{-1} \mathrm{Zn}$ (Martínez-Sánchez and Pérez-Sirvent 2007). The metal and As average concentrations at the Marina del Carmoli were in the range of the ones that other authors found for similar salt marshes affected by mining wastes around the Mar Menor lagoon (Álvarez-Rogel et al. 2004).

Compared to other European countries, the $\mathrm{Zn}$ and $\mathrm{Pb}$ soil concentrations obtained at the Marina del Carmoli surpassed the thresholds proposed for industrial use $\left(1,500 \mathrm{mg} \mathrm{kg}^{-1} \mathrm{Zn}\right.$ and $\left.1,000 \mathrm{mg} \mathrm{kg}^{-1} \mathrm{~Pb}\right)$ by Italy (Ministero dell'Ambiente dell'Italia 1999) and were more than 10 times higher than the Dutch intervention levels (720 $\mathrm{mg} \mathrm{kg}^{-1} \mathrm{Zn}$ and $530 \mathrm{mg} \mathrm{kg}^{-1} \mathrm{~Pb}$ ) (MHSPE 2000).

In general, rhizospheric soils showed higher total metal concentrations than bulk samples although both did not differ statistically for most of metals (Table 3). The same occurred for EDTA-extractable concentrations.

Plant metal and As uptake

The highest metal (except $\mathrm{Mn}$ ) and As concentrations in roots (Fig. 2) were obtained in P. australis: $\sim 66 \mathrm{mg} \mathrm{kg}^{-1} \mathrm{As}$, $\sim 1,770 \mathrm{mg} \mathrm{kg}^{-1} \mathrm{Zn}, \sim 58 \mathrm{mg} \mathrm{kg}^{-1} \mathrm{Cu}, \sim 1,780 \mathrm{mg} \mathrm{kg}^{-1}$ $\mathrm{Pb}$, and $\sim 17 \mathrm{mg} \mathrm{kg}^{-1} \mathrm{Cd}$. However, in relation to shoot uptake, the highest concentrations were species dependent, for example, $\sim 780 \mathrm{mg} \mathrm{kg}^{-1} \mathrm{Zn}$ in A. halimus, $\sim 16 \mathrm{mg} \mathrm{kg}^{-1}$ $\mathrm{Cu}$ in D. viscosa, and $\sim 175 \mathrm{mg} \mathrm{kg}^{-1} \mathrm{Mn}$ in H. portucaloides.

For most of plant species, metal concentrations in green shoots were higher than in dry shoots, for example, D. viscosa, $15 \mathrm{mg} \mathrm{kg}^{-1} \mathrm{Cu}$ for green shoots and $5 \mathrm{mg} \mathrm{kg}^{-1}$ $\mathrm{Cu}$ for dry shoots. Only for certain metals some species behaved oppositely, as it was the case of $\mathrm{Zn}$ in A. stipularis, or $\mathrm{Cu}$ in A. macrostachyum. 
Table 2 Characterization of the rhizospheric and bulk soil samples

\begin{tabular}{|c|c|c|c|c|c|c|c|c|}
\hline Type of soil & $\mathrm{pH}$ & $\begin{array}{l}\text { EC }(1: 2.5) \\
\left(\mathrm{dS} \mathrm{m} \mathrm{m}^{-1}\right)\end{array}$ & $\begin{array}{l}\text { Total } \\
N\left(\mathrm{~g} \mathrm{~kg}^{-1}\right)\end{array}$ & $\begin{array}{l}\mathrm{OC} \\
\left(\mathrm{g} \mathrm{kg}^{-1}\right)\end{array}$ & $\begin{array}{l}\mathrm{CaCO}_{3} \\
\left(\mathrm{~g} \mathrm{~kg}^{-1}\right)\end{array}$ & $\begin{array}{l}\text { Sand } \\
(\%)\end{array}$ & $\begin{array}{l}\text { Silt } \\
(\%)\end{array}$ & $\begin{array}{l}\text { Clay } \\
(\%)\end{array}$ \\
\hline Bulk & $7.10 \pm 0.36$ & $7.28 \pm 0.99$ & $0.75 \pm 0.17$ & $11.0 \pm 1.8$ & $45 \pm 12$ & $27 \pm 6$ & $49 \pm 6$ & $24 \pm 6$ \\
\hline A. machrostachyum* & $7.55 \pm 0.21$ & $8.93 \pm 1.10^{*}$ & $0.81 \pm 0.04$ & $16.7 \pm 4.7$ & $29.7 \pm 12.7$ & $7.0 \pm 2.6$ & $52.1 \pm 6.1$ & $40.9 \pm 6.9$ \\
\hline A. stipularis & $6.53 \pm 0.64$ & $2.78 \pm 0.25$ & $1.01 \pm 0.24$ & $17.4 \pm 5.5$ & $16.1 \pm 7.8$ & $44.2 \pm 9.7$ & $35.5 \pm 5.9$ & $20.3 \pm 3.8$ \\
\hline A. halimus & $7.24 \pm 0.50$ & $6.03 \pm 1.05$ & $1.55 \pm 0.58$ & $19.4 \pm 8.3$ & $40.5 \pm 26.0$ & $22.5 \pm 8.1$ & $45.0 \pm 6.4$ & $32.5 \pm 10.5$ \\
\hline D. viscosa & $7.61 \pm 0.19$ & $5.01 \pm 0.90$ & $1.42 \pm 0.57$ & $22.9 \pm 9.5$ & $50.9 \pm 19.8$ & $27.6 \pm 12.2$ & $37.0 \pm 2.6$ & $35.5 \pm 10.0$ \\
\hline F. vulgare* & $7.51 \pm 0.07$ & $2.70 \pm 0.06^{*}$ & $2.01 \pm 0.76^{*}$ & $23.2 \pm 8.0$ & $44.8 \pm 3.4$ & $40.9 \pm 13.4$ & $33.6 \pm 6.6$ & $25.5 \pm 7.3$ \\
\hline H. portulacoides & $7.53 \pm 0.32$ & $10.97 \pm 1.77$ & $2.26 \pm 1.42$ & $29.3 \pm 15.3$ & $23.3 \pm 11.3$ & $19.1 \pm 3.8$ & $56.7 \pm 12.4$ & $24.6 \pm 8.6$ \\
\hline J. maritumus & $7.61 \pm 0.23$ & $6.32 \pm 1.07$ & $1.15 \pm 0.21$ & $23.1 \pm 4.3$ & $27.2 \pm 16.7$ & $9.7 \pm 1.3$ & $53.6 \pm 14.2$ & $36.7 \pm 13.1$ \\
\hline L. cossonianum* & $7.83 \pm 0.27$ & $12.64 \pm 1.95^{*}$ & $1.41 \pm 0.56^{*}$ & $23.2 \pm 5.5$ & $48.4 \pm 17.2$ & $32.4 \pm 12.4$ & $41.2 \pm 6.3$ & $26.4 \pm 7.9$ \\
\hline L. spartum & $7.62 \pm 0.32$ & $9.52 \pm 2.00$ & $1.08 \pm 0.61$ & $19.4 \pm 7.2$ & $41.3 \pm 23.0$ & $15.6 \pm 3.5$ & $54.9 \pm 13.9$ & $30.0 \pm 17.3$ \\
\hline$P$. australis & $5.72 \pm 0.84$ & $4.98 \pm 0.76$ & $1.29 \pm 0.49$ & $16.6 \pm 11.2$ & $8.5 \pm 7.3$ & $17.3 \pm 4.8$ & $46.7 \pm 6.3$ & $36.1 \pm 11.0$ \\
\hline S. fruticosa* & $7.34 \pm 0.25$ & $10.69 \pm 2.04$ & $2.12 \pm 1.08^{*}$ & $16.1 \pm 3.2$ & $14.2 \pm 6.5$ & $18.2 \pm 6.7$ & $65.5 \pm 10.4$ & $16.4 \pm 3.7$ \\
\hline S. holoschoenus & $6.81 \pm 0.69$ & $4.38 \pm 0.54$ & $0.85 \pm 0.21$ & $12.5 \pm 4.0$ & $31.6 \pm 19.6$ & $23.3 \pm 13.0$ & $41.8 \pm 1.1$ & $34.9 \pm 14.0$ \\
\hline S. vera & $7.40 \pm 0.11$ & $9.32 \pm 2.79$ & $1.91 \pm 0.82$ & $20.1 \pm 10.5$ & $20.2 \pm 13.5$ & $27.0 \pm 17.0$ & $40.0 \pm 10.2$ & $33.0 \pm 12.7$ \\
\hline T. boveana & $7.06 \pm 0.43$ & $5.40 \pm 0.93$ & $1.38 \pm 0.63$ & $14.2 \pm 6.5$ & $28.5 \pm 27.6$ & $26.1 \pm 13.9$ & $47.0 \pm 14.7$ & $27.0 \pm 14.8$ \\
\hline
\end{tabular}

$E C$ electrical conductivity of the 1:2.5 soil:water suspension, $\mathrm{TN}$ total nitrogen, $\mathrm{OC}$ organic carbon, $\mathrm{CaCO}_{3}$ calcium carbonate content. Data are average \pm standard error. $N=9$ for bulk samples; $N=3$ or 4 for soil rhizospheric samples. ' $*$ ' means that there were significant differences in relation to the bulk soil $(P<0.05)$

Influence of soil parameters on plant colonization

The colonization of metal-polluted sites, and especially mining wastes, is normally slow because their physicochemical characteristics are not favourable for most of plant species. As a result, only metal-tolerant plant species are able to grow in these sites (Conesa et al. 2006). The time persistence of pollutants may decrease the community richness, due to the non-germination of seeds of non-tolerant species, which may lead to the exhaustion, with the time, of the diaspore bank (Trubina 2009). Conesa et al. (2006) affirmed that the colonization of mining wastes by pioneer vegetation is more affected by salinity and $\mathrm{pH}$ than by heavy metals. Several reviews performed on mining revegetation issues in semi-arid areas concluded that water scarcity and nutrient deficiency were important constraints for the phytostabilization of mining wastes (Mendez and Maier 2008; Conesa and Schulin 2010). For the specific case of mining-polluted salt marshes in coastal semi-arid areas, water availability is not expected to be a major constraint for plant development because water table can be easily explored by plant roots. In addition, in the case of the Marina del Carmoli, the nutrient-enriched waters of the local streams coming from the nearby intensive agricultural area of Campo de Cartagena flow into the salt marsh and provide high quantities of nutrients to the local vegetation (Álvarez-Rogel et al. 2007b). In fact, the Marina del Carmoli salt marsh has been shown to act as a green filter which decreases the inputs of nutrient-enriched water into de Mar Menor lagoon (Álvarez-Rogel et al. 2007a).
The comparison between bulk and rhizospheric soil samples of the metal-polluted area from the Marina de Carmoli salt marsh showed that factors such as $\mathrm{pH}$ or heavy metal concentrations were not the key for explaining plant colonization. However, EC values showed higher differences among the different rhizospheric soils studied: from $2.7 \mathrm{dS} \mathrm{m}^{-1}$ of A. stipularis and $F$. vulgare, to 10-12 dS m ${ }^{-1}$ of H. portulacoides, L. cossonianum, and $S$. fruticosa. This revealed that salinity played a more important role in determining plant establishment than metal pollution in spite of representing the latter the main gradients in the PCA (Fig. 3). It was hypothesized that a distribution based on low/high-salinity patches and not following gradients has determined the vegetation distribution within the sampled area. Figure 3 showed that the rhizospheric soils were distributed through the entire graph and that salinity (expressed as EC) had a minor influence on the environmental gradient. In fact, the main variables which had influence on soil conditions were the concentrations of $\mathrm{Cd}_{\mathrm{e}}, \mathrm{Cd}_{\mathrm{t}}, \mathrm{Mn}_{\mathrm{e}}, \mathrm{Zn}_{\mathrm{e}}$, and $\mathrm{Zn}_{\mathrm{t}}$, and $\mathrm{pH}$. The variability along the $Y$ axes was due to $\mathrm{Cu}_{\mathrm{t}}, \mathrm{Pb}_{\mathrm{t}}$, and $\mathrm{As}_{\mathrm{t}}$ (on the positive side) and sand, $\mathrm{CaCO}_{3}$, and $\mathrm{Mn}_{\mathrm{t}}$ (on the negative side). Most of the EDTA-extractable metal(loids)s $\left(\mathrm{Zn}_{\mathrm{e}}, \mathrm{Cu}_{\mathrm{e}}, \mathrm{Pb}_{\mathrm{e}}\right.$, and $\left.\mathrm{As}_{\mathrm{e}}\right)$ correlated with $\mathrm{OC}$ and $\mathrm{TN}$ (quadrant I of the diagram) but not with their respective total concentrations $\left(\mathrm{Cut}, \mathrm{Pb}_{\mathrm{t}}\right.$, and $\mathrm{As}_{\mathrm{t}}$ lay in quadrant $\left.\mathrm{I}\right)$. It might be hypothesized that the bioavailability of these metals could have been enhanced in the rhizospheric soils, which were shown to have higher TN and OC contents. Moreover, most of the bulk soil samples were depicted on 


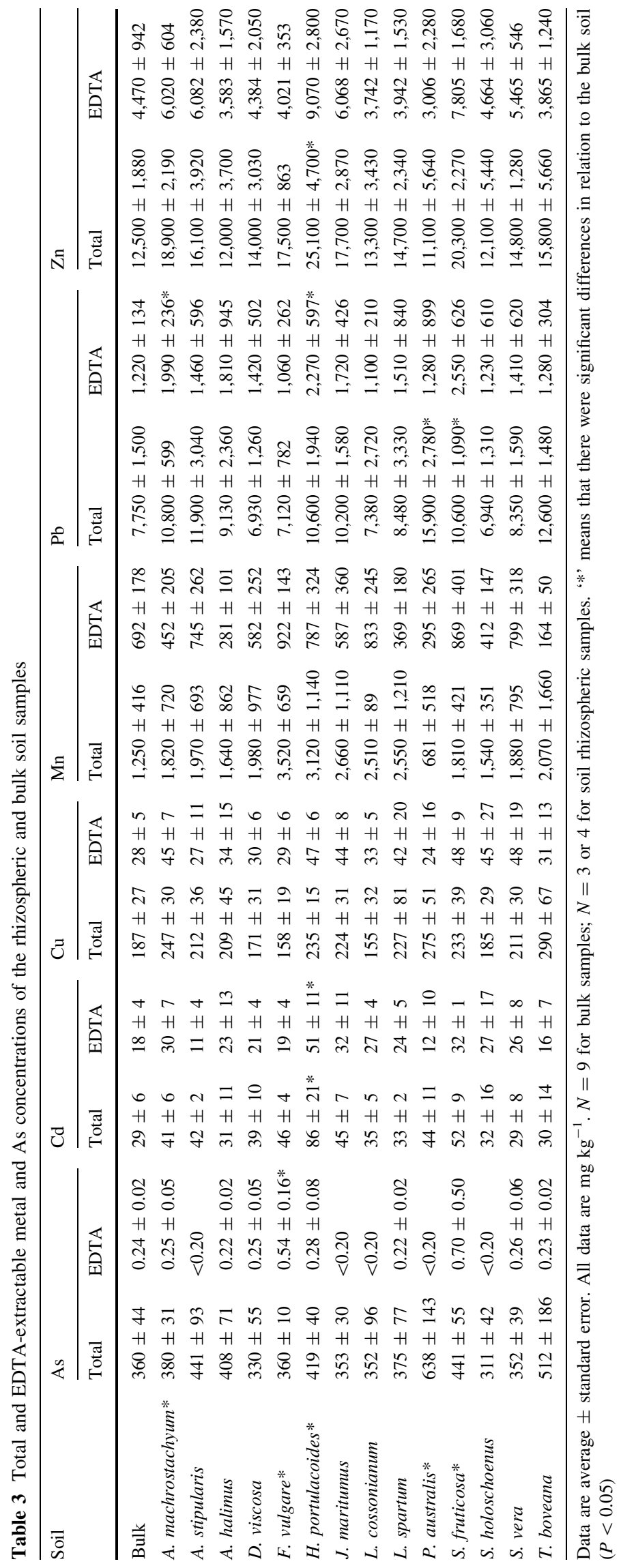


Fig. 2 Metal and As plant uptake for each plant species. Black bar on columns represents standard deviation $(N=3)$.

*Means that samples were below the detection limit. Black columns represent roots, white columns green shoots, and square filled columns dry shoots (only in A. macrostachyum,

A. stipularis, A. halimus,

$H$. portulacoides, S. fruticosa,

$S$. vera, and $T$. boveana)
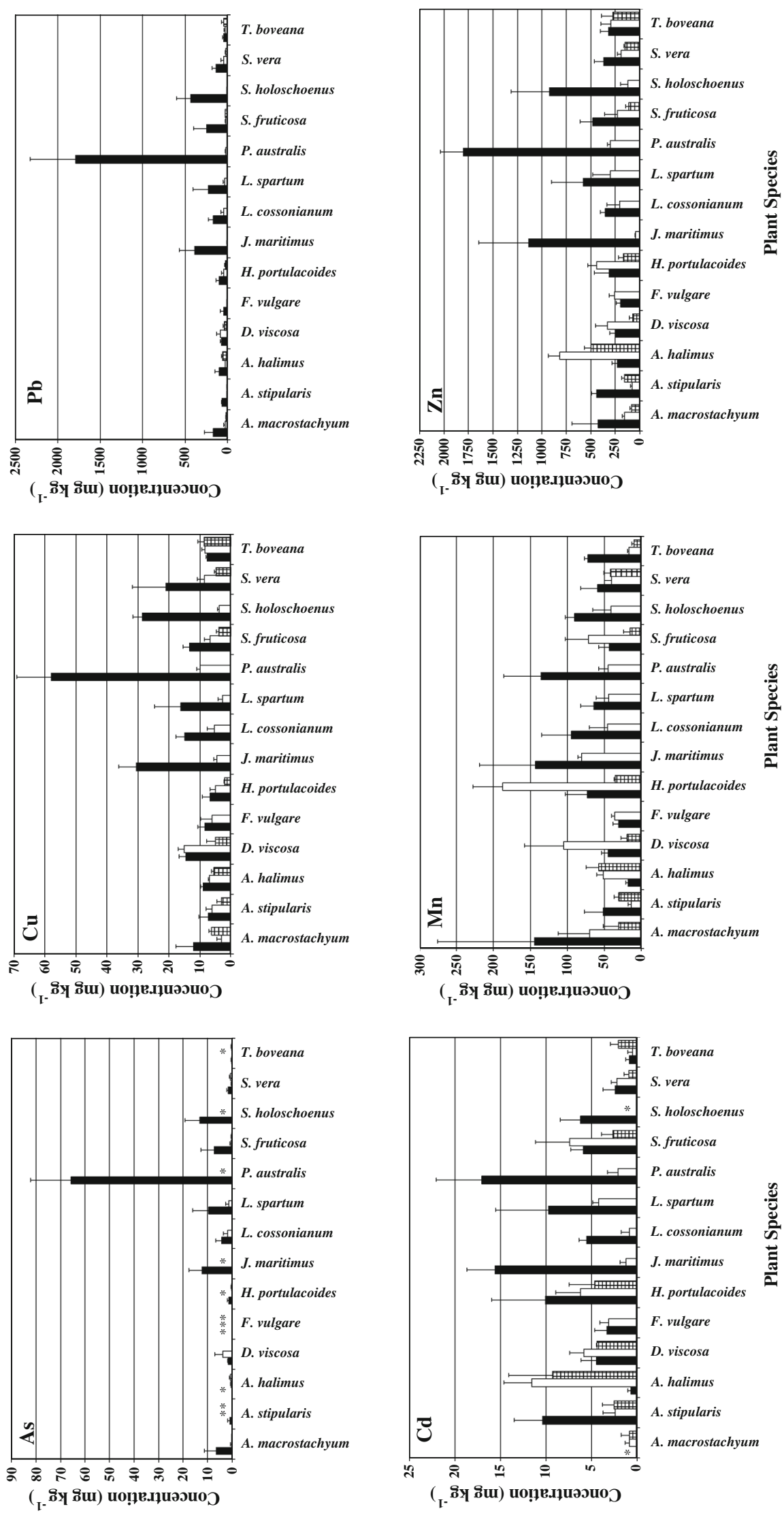
Fig. 3 PCA for all the studied plots and soil parameters. $E C$ electrical conductivity, $O C \%$ organic carbon, $T N \%$ of total nitrogen, $M_{t}$ total metal(loid)s' concentrations, $M_{e}$ metal(loid)s' EDTA-extractable concentrations. Variance explained by the two first axis $53.4 \%$ ( $X$ axes $31.5 \%$; $Y$ axes $21.9 \%)$
PCA Axis 1 (scale for environmental variables)

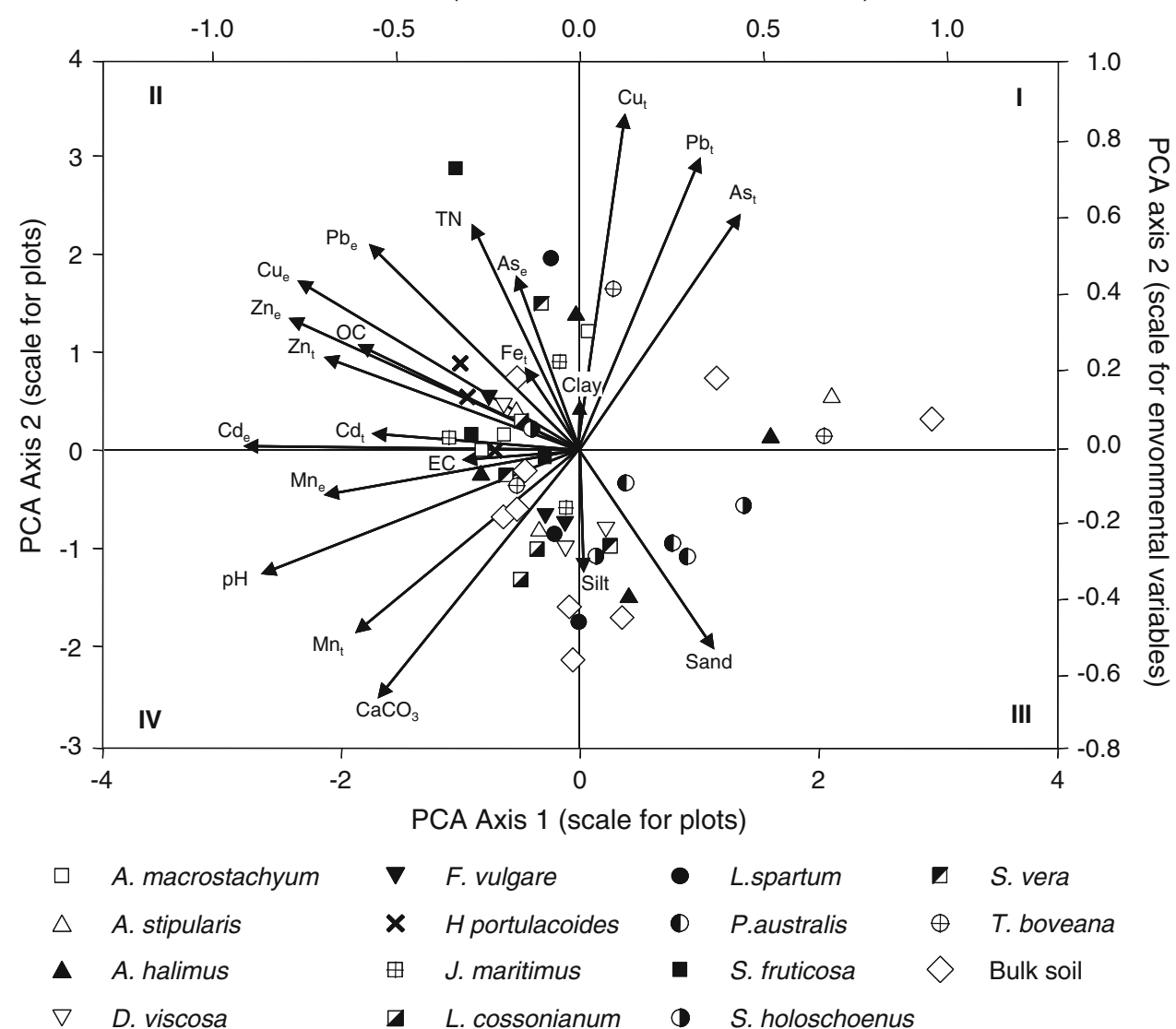

the negative side of $Y$ axes which showed lower OC and $\mathrm{TN}$, together with lower EDTA-extractable $\mathrm{Zn}_{\mathrm{e}}, \mathrm{Cu}_{\mathrm{e}}, \mathrm{Pb}_{\mathrm{e}}$, and $\mathrm{As}_{\mathrm{e}}$ concentrations. $\mathrm{Mn}_{\mathrm{t}}$ was strongly correlated with $\mathrm{CaCO}_{3}$ as it could be seen in Fig. 3 where their respective arrows are almost coincidental. The latter was in agreement with the findings of Jiménez-Cárceles et al. (2008) that showed that most of the Mn present in the Marina del Carmoli was bound to carbonates.

According to Conesa et al. (2007a), pioneer vegetation may 'invade' mining wastes by three mechanisms: (1) improving soil properties by releasing root exudates, which favours the further growing and establishment of the plant species; (2) growing at patches where soil conditions are more favourable for initial plant establishment (water availability, lower salinity, etc.) and successively 'improve' the quality of the colonized soil; and (3) selectively root growth into the soil, taking advantage of the heterogeneity in the distribution of metals, that is, by avoiding the most contaminated patches. Although no significant differences occurred, nitrogen and organic carbon contents were higher in the rhizospheric soils than in the bulk soil samples. As it is known, rhizosphere may be enriched with root exudates and support more microbiological activity than bulk soil (Carrasco et al. 2006). This may facilitate the plant establishment and ameliorate phytotoxicity.

Finally, some of the species from the Marina del Carmoli are able to grow through rhizomes (e.g. P. australis, L. spartum, J. maritimus), which has been shown to be a more suitable way of success in the colonization of mining wastes by pioneer vegetation (Conesa et al. 2007a).

Metal phytoavailability changes in the rhizosphere assessed by EDTA

The rhizospheric soils of the plant species sampled in the Marina del Carmoli showed slightly higher total, EDTA, metal, and As concentrations than in the bulk soil samples. This behaviour agrees with the results of Almeida et al. (2006) that found higher total metal concentrations in the rhizosphere of J. maritimus than in the surrounding bulk soil. The reason for this metal enrichment could be explained by the formation of metal-enriched concretions on the roots of plant species at salt marshes (Sundby et al. 1998). In addition, this behaviour has been also shown by Conesa et al. (2006) in the rhizospheres of the pioneer vegetation which grew at tailings of the Cartagena-La Unión Mining area. These authors found plant species such 
as L. spartum and P. australis which also were present at the Marina del Carmoli.

The ratios EDTA/total concentrations (data not shown) showed no differences when comparing bulk soil samples and the rhizospheric ones, which indicated that the bioavailability assessed by EDTA was not influenced by rhizosphere. In spite of being widely employed for the assessment of plant metal bioavailability in polluted soils (Aguilar et al. 2007), it might be admitted that EDTA could not be the most suitable reagent to assess metal bioavailability changes in the rhizosphere of high salty metal-polluted soils and then weaker reagents could be used instead. Furthermore, it has been shown that in highly polluted soils, EDTA is able to extract between 40 and $100 \%$ of the total Pb (Nowack et al. 2006).

However, the differences occurred when comparing metals. Cadmium showed the highest values for the ratio EDTA/total concentration $(\sim 60 \%)$. For $\mathrm{Mn}$ and $\mathrm{Zn}$ this ratio ranged between 25 and $45 \%$, while for $\mathrm{Cu}$ and $\mathrm{Pb}$ it was of around $20 \%$. Previous works have shown that $\mathrm{Cd}$ and to a lesser extent $\mathrm{Cu}$ and $\mathrm{Zn}$ are more available under high-salinity conditions (Du Laing et al. 2009a).

Plant species and metal uptake

Some of the plant species found in the Marina del Carmoli salt marsh, such as D. viscosa, L. cossonianum, L. spartum, $P$. australis, or $T$. boveana, have been found growing in tailings from the nearby Cartagena-La Unión area (Conesa et al. 2007b).

Among the species sampled, two groups could be distinguished:

(a) a group composed of plant species which are characteristic of salt marshes such as $P$. australis, A. macrostachyum, or S. Fruticosa. Most of these species can be considered as halophyte and therefore are adapted to grow in extremely salty environments. Several authors have shown the relation between salttolerant mechanisms in halophyte species and metal tolerance (Otte 2001). For instance, halophyte plant species have been shown to have a better system to compartmentalization of salts, well-developed antioxidant system, and osmoprotectants that may also act in case of metal stress (Manousaki and Kalogerakis 2011);

(b) a group of plant species, which are exogenous to these salt marsh ecosystems but that are able to colonize disturbed environments. In this group plant species such as D. viscosa, F. vulgare, or A. stipularis were included. The introduction of exogenous plant species with lower ecological requirements may promote the recovery of the soil quality by improving soil structure and microbial activity and increasing organic matter content. Therefore, it may contribute positively to the site phytomanagement. However, the establishment of these exogenous species may disturb the ecological relationships of the ecosystem in the long term. Then, it is necessary to monitor the ecological relationships of the plant species involved to ensure that the decrease in the environmental risks is compatible with the maintaining of the local biodiversity.

The uptake into shoots showed in Fig. 2 (e.g. up to $12 \mathrm{mg} \mathrm{kg}^{-1} \mathrm{Cd}$, up to $16 \mathrm{mg} \mathrm{kg}^{-1} \mathrm{Cu}$, or up to 800 $\mathrm{mg} \mathrm{kg}^{-1} \mathrm{Zn}$ ) was lower than the thresholds which Brooks (1998) proposed for hyperaccumulators $\left(100 \mathrm{mg} \mathrm{kg}^{-1} \mathrm{Cd}\right.$, $5,000 \mathrm{mg} \mathrm{kg}^{-1} \mathrm{Cu}$, and $\left.10000 \mathrm{mg} \mathrm{kg}^{-1} \mathrm{Zn}\right)$. Cadmium concentrations in $P$. asutralis shoots $\left(\sim 4.5 \mathrm{mg} \mathrm{kg}^{-1}\right)$ were about 10 times higher than those found by other authors in metal-polluted intertidal freshwater and brackish water marshes (Du Laing et al. 2009b). This should probably be attributed to the role of salinity, in more particular to the increased cation exchange and $\mathrm{Cd}$-chloride complex formation with higher EC, which increases $\mathrm{Cd}$ bioavailability and mobility (Usman et al. 2005; Du Laing et al. 2008).

Moreover, the concentrations uptaked were higher than some of the maximum levels tolerated by live stock proposed by Chaney (1989), for example, $0.5 \mathrm{mg} \mathrm{kg}^{-1} \mathrm{Cd}$, $30 \mathrm{mg} \mathrm{kg}^{-1} \mathrm{~Pb}$, or $300 \mathrm{mg} \mathrm{kg}^{-1} \mathrm{Zn}$. Furthermore, factors such as metal-rich dust particles adhering to the surfaces or the direct ingestion of soil by cattle may play an important role for the transfer of the metals into the food chain (Conesa et al. 2009).

An important issue refers to those plant species which may be consumed by the population such as A. stipularis, $S$. fruticosa, or $F$. vulgare. The metal concentrations uptaked by these species were compared with the maximum thresholds for food safety established by the European Community (2001) for $\mathrm{Pb}\left(0.1 \mathrm{mg} \mathrm{kg}^{-1}\right)$ and $\mathrm{Cd}$ in fresh vegetables and fruits $\left(0.05 \mathrm{mg} \mathrm{kg}^{-1}\right)$. The concentrations obtained in the plant samples and showed in Fig. 2 (up to $2.6 \mathrm{mg} \mathrm{kg}^{-1} \mathrm{~Pb}$ and up to $1.15 \mathrm{mg} \mathrm{kg}^{-1} \mathrm{Cd}$, fresh weight) were higher than the aforementioned thresholds.

No general trend was observed in relation to metal concentrations when comparing green shoots and dry shoots. It is known that some plant species may develop mechanisms of metal tolerance based on excretion by leaves and deposition onto soil. For instance, Manousaki et al. (2008) studied Tamarix smyrnensis (a typical salt marsh species) and its response to solution with increasing salinity and $\mathrm{Cd}$ concentrations, concluding that the mechanisms of salt excretion in the leaves of this species were also employed to excrete $\mathrm{Cd}$. 
Bioconcentration and accumulation factors

Plant metal accumulation is often expressed as a bioconcentration factor (BF). It is calculated as the dry plant tissue/soil metal concentration quotient (Mattina et al. 2003). McGrath and Zhao (2003) considered $<0.2$ normal for plants growing on polluted materials. For most of metals and plant species studied at the Marina del Carmolí salt marsh, BF values were below 0.2 for both roots $\left(\mathrm{BF}_{\mathrm{ROOT}}\right)$ and shoots $\left(\mathrm{BF}_{\mathrm{SHOOT}}\right)$. However, for $\mathrm{Cd}$ some species showed values between 0.2 and 1 (BF ROOT $\left._{1}\right)$. For instance, $P$. australis and $S$. holoschoenus showed $\mathrm{BF}_{\mathrm{ROOT}}$ of around 0.5-0.6. P. australis also reached $\mathrm{BF}_{\mathrm{ROOT}}$ of 0.4 for $\mathrm{Mn}$ and 0.2 for $\mathrm{Cu}$ and $\mathrm{Zn}$. It is known that plant species such as $P$. australis have low translocation of metals into shoots and tend to accumulate metals into roots (Burke

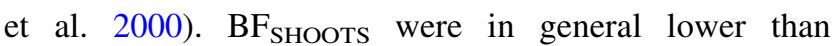
$\mathrm{BF}_{\mathrm{ROOTS}}$ except for A. halimus.

The accumulation factor (AF) (data not shown) indicates the efficacy of metal translocation from roots into shoots (Fitz and Wenzel 2002). Also called translocation factor (Mattina et al. 2003), it is the shoot/root metal concentration quotient. Excluder plants have AF values $\ll 1$, whereas for hyperaccumulators it is $\gg 1$. The green shoot/root metal concentration was employed to calculate this ratio. In general, AF values were below 1, except D. viscosa which showed $\mathrm{AF}$ of around 2 for $\mathrm{Cd}$ and $\mathrm{Mn}$; A. halimus, with $\mathrm{AF}$ values of 6 for $\mathrm{Cd}, 3$ for $\mathrm{Mn}$, and 4 for $\mathrm{Zn}$; and finally, H. portulacoides which showed AF of around 6 for Mn, 3 for $\mathrm{Pb}$, and 2 for $\mathrm{Zn}$. Similar to the results showed in this study, Gonzalez-Fernandez et al. (2011) obtained AF of 2 for $\mathrm{Zn}$ and 1.5 for $\mathrm{Pb}$ in shoots of $D$. viscosa from the nearby mining area.

\section{Conclusion}

The assessment of bioavailability of metals and As between rhizospheric and bulk soil samples in a miningpolluted Mediterranean salt marsh did not show significant differences. Vegetation distribution in the polluted area of the Marina del Carmoli looked to be more affected by salinity patches than by metal pollution. It can be hypothesized that the free availability of water and the incoming nutrient-enriched waters which flow through the salt marsh may have hindered the phytotoxic effects of metal pollution.

The phytomanagement of these polluted areas employing the spontaneous vegetation is a good option in order to improve the ecological indicators of the soil and to prevent the erosion and transport of pollutants to nearby areas, but it must be compatible with the maintenance of low levels of metal transfer into the food chain. The fencing of some areas in La Marina del Carmoli salt marsh should be considered by authorities to prevent cattle or people of consuming plants with high metal shoot uptake such as Sarcocornia fruticosa or Arthrocnemum macrostachyum.

Acknowledgments Support for this research was provided by the Ministerio de Ciencia y Tecnología of Spain (REN 2004-05807 and CGL 2007-64915) and Fundacion Séneca de la Comunidad Autónoma de la Región de Murcia (Project 15296/PI/10). Dr. Héctor M. Conesa thanks the Spanish Ministerio de Economia y Competitividad and UPCT for funding through the 'Ramon y Cajal' programme (Ref. RYC-2010-05665). M. N. González-Alcaraz and A. María-Cervantes received pre-doctoral grants (FPU) financed by the Ministerio de Educación y Ciencia of Spain (MEC).

\section{References}

Aguilar J, Dorronsoro C, Fernández E, Fernández J, García I, Martín F, Sierra M, Simón M (2007) Arsenic contamination in soils affected by a pyrite-mine spill (Aznalcóllar, SW Spain). Water Air Soil Pollut 180:271-281

Alarcón-Vera AL (2004) Diagnóstico agrícola. Escuela Técnica Superior de Ingeniería Agronómica de Cartagena, Cartagena

Almeida CMR, Mucha AP, Vasconcelos MTSD (2006) Variability of metal contents in the sea rush Juncus maritimus-estuarine sediment system through one year of plant's life. Mar Environ Res 61:424-438

Álvarez-Rogel J, Ramos MJ, Delgado MJ, Arnaldos R (2004) Metals in soils and above-ground biomass of plants from a salt marsh polluted by mine wastes in the coast of the Mar Menor lagoon, SE Spain. Fresen Environ Bull 13:274-278

Álvarez-Rogel J, Jimenez-Carceles FJ, Egea-Nicolas C (2006) Phosphorus and nitrogen content in the water of a coastal wetland in the Mar Menor Lagoon (SE Spain): relationships with effluents from urban and agricultural areas. Water Air Soil Pollut 173:21-38

Álvarez-Rogel J, Jiménez-Cárceles FJ, Egea-Nicolás C (2007a) Phosphorus retention in a coastal salt marsh in SE Spain. Sci Total Environ 378:71-74

Álvarez-Rogel J, Jimenez-Carceles FJ, Roca MJ, Ortiz R (2007b) Changes in soils and vegetation in a Mediterranean coastal salt marsh impacted by human activities. Estuar Coast Shelf Sci 73:510-526

Brooks RR (1998) Geobotany and hyperaccumulators. In: Brooks RR (ed) Plants that hyperaccumulate heavy metals. CAB International, Wallingford, pp 55-94

Burke DJ, Weis JS, Weis P (2000) Release of metals by the leaves of the salt marsh grasses Spartina alterniflora and Phragmites australis. Estuar Coast Shelf Sci 51:153-159

Caçador I, Caetano M, Duarte B, Vale C (2009) Stock and losses of trace from salt marsh plants. Mar Environ Res 67:75-82

Carrasco L, Caravaca F, Álvarez-Rogel J, Roldán A (2006) Microbial processes in the rhizosphere soil of a heavy metals-contaminated Mediterranean salt marsh: a facilitating role of $\mathrm{AM}$ fungi. Chemosphere 64:104-111

Chaney RL (1989) Toxic element accumulation in soils and crops: protecting soil fertility and agricultural food-chains. In: BarYosef B, Barrow NJ, Goldshmid J (eds) Inorganic contaminants in the vadose zone. Springer, Berlin, pp 140-158

Conesa HM, Jiménez FJ (2007) The Mar Menor lagoon (SE Spain): a singular natural ecosystem threatened by human activities. Mar Pollut Bull 54:839-879 
Conesa HM, Schulin R (2010) The Cartagena-La Unión mining district (SE Spain): a review of environmental problems and emerging phytoremediation solutions after fifteen years research. J Environ Monit 12:1225-1233

Conesa HM, Faz Á, Arnaldos R (2006) Tolerant plant species to heavy metals that grow at mining tailings in the semiarid Cartagena-La Union mining district (SE Spain). Sci Total Environ 36:1-11

Conesa HM, Robinson BH, Schulin R, Nowack B (2007a) Growth of Lygeum spartum in acid mine tailings: response of plants developed from seedlings, rhizomes and at field conditions. Environ Pollut 145:700-707

Conesa HM, García G, Faz Á, Arnaldos R (2007b) Dynamics of metal tolerant plant communities' development in mine tailings from the Cartagena-La Unión Mining District (SE Spain) and their interest for further revegetation purposes. Chemosphere 68:1180-1185

Conesa HM, Moradi AB, Robinson BH, Kühne G, Lehmann E, Schulin R (2009) Response of native grasses and Cicer arietinum to soil polluted with mining wastes: implications for the management of land adjacent to mine sites. Environ Exp Bot 65:198-204

Damkröger G, Grote M, Janßen E (1997) Comparison of sample digestion procedures for the determination of arsenic in certified marine samples using the FI-HG-AAS-technique. Fresen J Anal Chem 357:817-821

Dhir B, Sharmila P, Pardha-Saradhi P (2009) Potential of aquatic macrophytes for removing contaminants from the environment. Crit Rev Environ Sci Technol 39:754-781

Domínguez MT, Marañón T, Murillo JM, Schulin R, Robinson BH (2008) Trace element accumulation in woody plants of the Guadiamar Valley, Sw, Spain: a large-scale phytomanagement study. Environ Pollut 152:50-59

Du Laing G, De Vos R, Vandecasteele B, Lesage E, Tack FMG, Verloo MG (2008) Effect of salinity on heavy metal mobility and availability in intertidal sediments of the Scheldt estuary. Estuar Coast Shelf Sci 77:589-602

Du Laing G, Meers E, Dewispelaere M, Rinklebe J, Vandecasteele B, Verloo MG, Rack FMG (2009a) Effect of water table level on metal mobility at different depths in wetland soils of the Scheldt Estuary (Belgium). Water Air Soil Pollut 202:353-367

Du Laing G, Van de Moortel AMK, Moors W, De Grauwe P, Meers E, Tack FMG, Verloo MG (2009b) Factors affecting metal concentrations in reed plants (Phragmites australis) of intertidal marshes in the Scheldt estuary. Ecol Eng 35:310-318

Dudka S, Adriano DC (1997) Environmental impacts of metal ore mining and processing: a review. J Environ Qual 26:590-602

Fitz WJ, Wenzel WW (2002) As transformations in the soilrhizosphere plant system: fundamentals and potential application to phytoremediation. J Biotechnol 99:259-278

Gee GW, Bauder JW (1986) Particle-size analysis. In: Klute A (ed) Methods of soil analysis. Part 1: physical and mineralogical methods, 2nd edn. American Society of Agronomy and Soil Science Society of America, Madison, pp 383-410

González-Alcaraz MN, Egea C, María-Cervantes A, Jiménez-Cárceles FJ, Álvarez-Rogel J (2011) Effects of eutrophic water flooding on nitrate concentrations in mine wastes. Ecol Eng 37:693-702

Gonzalez-Fernandez O, Queralt I, Carvalho ML, García G (2011) Lead, zinc, arsenic and copper pollution in the alluvial plain of a mining wadi: the Beal case (Cartagena-La Union Mining District, SE Spain). Water Air Soil Pollut 220:279-291

Hulseman J (1966) An inventory of marine carbonate materials. J Sediment Petrol ASCE 36:622-625

Jiménez-Cárceles FJ, Álvarez-Rogel J, Conesa HM (2008) Trace element concentrations in saltmarsh soils strongly affected by wastes from metal sulphide mining areas. Water Air Soil Pollut 188:283-295

Jogman RHG, ter Braak CJF, van Tongeren OFR (1987) Data analysis in community and landscape ecology. Pudoc, Wageningen

Manousaki E, Kalogerakis N (2011) Halophytes present new opportunities in phytoremediation of heavy metals and saline soils. Ind Eng Chem Res 50:656-660

Manousaki E, Kadukova J, Papadantonakus N, Kalogerakis N (2008) Phytoextraction and phytoexcretion of $\mathrm{Cd}$ by the leaves of Tamarix smyrnensis growing on saline and non-saline soils. Environ Res 106:326-332

María-Cervantes A, Conesa HM, González-Alcaraz MN, ÁlvarezRogel J (2010) Rhizosphere and flooding regime as key factors for the mobilisation of arsenic and potentially harmful metals in basic, mining polluted salt marsh soils. Appl Geochem 25:1722-1733

Martínez-Sánchez MJ, Pérez-Sirvent C (2007) Niveles de fondo y niveles genéricos de referencia de metales pesados en suelos de la Región de Murcia. Universidad de Murcia. Región de Murcia, Consejería de Desrrollo Sostenible y Ordenación del Territorio. Murcia, Spain

Mattina MI, Lannucci-Berger W, Musante C, White JC (2003) Concurrent plant uptake of heavy metals and persistent organic pollutants from soil. Environ Pollut 124:375-378

McGrath SP, Zhao FJ (2003) Phytoextraction of metals and metalloids from contaminated soils. Curr Opin Biotechnol 14:277-282

Mendez MO, Maier RM (2008) Phytoremediation of mine tailings in temperate and arid environments. Rev Environ Sci Biotechnol $7: 47-59$

MHSPE (Ministry of Housing, Spatial Planning and Environment) (2000) Netherlands. Circular on target values and intervention values for soil remediation. Ministry of Housing, Spatial Planning and Environment 422000

Ministero dell'Ambiente dell'Italia (1999) Regolamento recante criteri, procedure e modalità per la messa in sicurezza, la bonifica e il ripristino ambientale dei siti inquinati, ai sensi dell'articolo 17 del decreto legislativo 5 febbraio 1997, n. 22, e successive modificazioni e integrazioni. Italian Ministerial Decree 471/99, Gazzetta Ufficiale no 293, 15/12/99, supl. Ordinario no 218

Mitsch WJ, Gosselink JG (2007) Wetlands, 4th edn. Willey, Hoboken, NJ

Muller G, Gastner M (1971) Chemical analysis. Neues Jahrbuch für Mineralogie Monatshefte 10:466-469

Nowack B, Van Briesen J (2005) Chelating agents in the environment. In: Nowack B, Van Briesen J (eds) Biogeochemistry of chelating agents, ACS symposium series, vol 910, pp 1-18

Nowack B, Schulin R, Robinson BH (2006) A critical assessment of chelant-enhanced metal phytoextraction. Environ Sci Technol 40:5225-5232

O‘Sullivan AD, Moran BM, Otte ML (2004) Accumulation and fate of contaminants $(\mathrm{Zn}, \mathrm{Pb}, \mathrm{Fe}$ and $\mathrm{S})$ in substrates of wetlands constructed for treating mine wastewater. Water Air Soil Pollut 157:345-364

Otte ML (2001) What is stress to a wetland plant? Environ Exp Bot 46:195-202

Prasad MNV, Greger M, Aravind P (2006) Biogeochemical cycling of trace elements by aquatic and wetland plants: relevance to phytoremediation. In: Prasad MNV, Sajwan KS, Naidu R (eds) Trace elements in the environment. Taylor and Francis, CRC Press, Boca Raton, FL, pp 451-482

Quevauviller Ph, Lachica M, Barahona E, Gomez A, Rauret G, Ure A, Muntau H (1998) Certified reference material for the quality control of EDTA- and DTPA-extractable trace metal contents in calcareous soil (CRM 600). Fresen J Anal Chem 360:505-511 
Rayment GE, Lyons DJ (2011) Soil chemical methods-Australasia. CSIRO, Collingwood

Robinson BH, Schulin R, Nowack B, Roulier S, Menon M, Clothier B, Green S, Mills T (2006) Phytoremediation for the management of metal flux in contaminated sites. For Snow Landsc Res 80:221-224

Robinson BH, Bischofberger S, Stoll A, Schroer D, Furrer G, Roulier S, Gruenwald A, Attinger W, Schulin R (2008) Plant uptake of trace elements on a Swiss military shooting range: uptake pathways and land management implications. Environ Pollut 153:668-676

Robinson BH, Bañuelos G, Conesa HM, Evangelou MWH, Schulin R (2009) The phytomanagement of trace elements in soil. Crit Rev Plant Sci 28:240-266

Simón M, Ortiz I, García I, Fernández E, Fernández J, Dorronsoro C, Aguilar J (1999) Pollution of soils by the toxic spill of a pyrite mine (Aznalcollar, Spain). Sci Total Environ 242:105-115

Sundby B, Vale C, Caçador I, Catarino F, Madureira M-J, Caetano M (1998) Metal-rich concretions on the roots of salt marsh plants: mechanism and rate of formation. Limnol Oceanogr 43:245-252

ter Braak CJ, Smilauer FP (1999) Canoco for windows v. 4.02. Centre for Biometry Wageningen CPRO-DLO, Wageningen

Trubina MR (2009) Species richness and resilience of forest communities: combined effects of short-term disturbance and long-term pollution. Plant Soil 201:339-350

UIB (Universitat de les Illes Balears) (2007) Herbari Virtualde les Illes Balears. Laboratori de Botànica, Dept. de Biologia Universitat de les Illes Balears. Palma de Mallorca. (Spain). Online: http://herbarivirtual.uib.es/eng/index.html. Accessed 28 Feb 2011

USDA (United States Department of Agriculture) (1996) Soil survey laboratory methods manual. Soil survey investigations Report No. 42

USDA (United States Department of Agriculture) (2005) Natural resources conservation service. National soil survey handbook,
2005; title 430-VI. [Online] http://soils.usda.gov/technical/ handbook/. Accessed 21 July 2011

USEPA (United States Environmental Protection Agency) (1996) Method 3052: microwave assisted acid digestion of siliceous and organically based matrices, Washington, DC. http://www.epa. gov/epawaste/hazard/testmethods/sw846/pdfs/3052.pdf. Accessed 8 Mar 2011

Usman ARA, Kuzyakov Y, Stahr K (2005) Effect of immobilizing substances and salinity on heavy metals availability to wheat grown on sewage sludge-contaminated soil. Soil Sediment Contam 14:329-344

Viaroli P, Lasserre P, Campostrini P (2007) Lagoons and coastal wetlands. Hydrobiologia 577:1-3

Wang EX, Benoit G (1996) Mechanisms controlling the mobility of lead in the spodosols of a northern hardward forest ecosystem. Environ Sci Technol 30:2211-2219

Weis JS, Weis P (2004) Metal uptake, transport and release by wetland plants: implications for phytoremediation and restoration. Environ Int 30:685-700

Weis P, Windham L, Burke D, Weis J (2002) Release into the environment of metals by two vascular salt marsh plants. Mar Environ Res 54:325-329

Wenzel WW (2009) Rhizosphere processes and management in plantassisted bioremediation (phytoremediation) of soils. Plant Soil 321:385-408

Williams JB (2002) Phytoremediation in wetland ecosystems: progress, problems, and potential. Crit Rev Plant Sci 21:607-635

Ybáñez N, Cervera ML, Montoro R, De la Guardia M (1991) Comparison of dry mineralization and microwave-oven digestion for the determination of arsenic in mussel products by platform in furnace Zeeman-effect atomic absorption spectrometry. J Anal Atom Spectrom 6:379-384 